\title{
Maximizing Nitrogen-use Efficiency in Relation to the Growth and Development of Poinsettia
}

\author{
Mary Ann Rose', John W. White ${ }^{2}$, and Mark A. Rose ${ }^{3}$ \\ Department of Horticulture, The Pennsylvania State University, University \\ Park, PA 16802
}

Additional index words. Euphorbia pulcherrima, growth analysis, $\mathrm{N}$ fertilization, $\mathrm{N}$ accumulation, $\mathrm{N}$ allocation, nutrition, subirrigation

\begin{abstract}
Celebrate 2' poinsettias (Euphorbia pulcherrima Willd.) received either a constant application rate of $200 \mathrm{mg}$ N/liter or a variable rate that was linked to the $\mathrm{N}$ accumulation pattern of the crop. At final harvest, shoot $N$ content, $N$ concentration, dry weight, leaf area, and quality were similar for the treatments. However, $N$ recovery efficiency of the variable treatment was greater $(58 \%$ vs. $38 \%)$, and $41 \%$ less total $\mathrm{N}$ was applied compared to the constant-rate treatment. Growth analysis revealed that $\mathbf{N}$ accumulation rates for both treatments increased rapidly as side branches developed, reaching a maximum 50 to 60 days after potting, and decreased throughout bract development. The decrease in $\mathrm{N}$ accumulation rates after day 60 reflected a shift in $\mathrm{N}$ allocation from leaves to bracts, a tissue with a lower $\mathbf{N}$ concentration.
\end{abstract}

In recent years, research on fertilizer form (Hershey and Paul, 1982), frequency of application (Stewart et al., 1981), application rate and method (Yelanich and Biernbaum, 1990), and irrigation control technology (Newman et al., 1992) have provided growers with effective options for increasing fertilizer and wateruse efficiency. However, most nutrient-use studies have used fixed concentrations of fertilizer throughout the course of experimentation, despite evidence that plant nutrient requirements change with growth stage (King and Stimart, 1990). One exception was a study by Argo and Biernbaum (1991), in which poinsettias were given either a constant rate of $400 \mathrm{mg} \mathrm{N} /$ liter or a variable rate that increased from 0 to $400 \mathrm{mg} \mathrm{N} /$ liter in 5 weeks. At weeks 3 and 8 of the experiment, root and shoot growth decreased significantly in the constant-rate treatment compared to the variablerate treatment.

In our experiment, a similar sliding application rate was used through an 80-day poinsettia production cycle. The first objective of this work was to use growth analysis to confirm the $\mathrm{N}$ accumulation patterns of poinsettia observed in previous experiments, and second, to determine whether $\mathrm{N}$ fertilizer might be applied more efficiently by linking the $\mathrm{N}$ supply to plant uptake. The ultimate goal was to minimize the $\mathrm{N}$ input in crop production while maintaining quality.

\footnotetext{
Received for publication 14 July 1993 . Accepted for publication 6 Nov. 1993. This paper is a portion of a thesis submitted to the Graduate School, The Pennsylvania State Univ., by M.A.R. in partial fulfillment of the PhD degree, The cost of publishing this paper was defrayed in part by the payment of page charges. Under postal regulations, this paper therefore must be hereby marked advertisement solely to indicate this fact.

'Graduate Student.

Professor Emeritus.

Senior Research Aide.
}

\section{Materials and Methods}

Culture. Rooted cuttings of 'Celebrate 2' poinsettia were potted in 1250 -ml pots containing 2 peat : 1 perlite : 1 vermiculite medium (by volume) amended (per cubic meter) with $0.6 \mathrm{~kg}$ superphosphate, $1.2 \mathrm{~kg}$ dolomitic lime, $3.0 \mathrm{~kg}$ calcitic lime, and $0.9 \mathrm{~kg}$ trace elements (Micromax Micronutrients; GraceSierra Horticultural Products, Fogelsville, Pa.), Plants were placed in a growth room with day/ night means of $24.0 \pm 0.7 \mathrm{C}$ and $19.1 \pm 0.7 \mathrm{C}$. Fluorescent $\mathrm{CW} / \mathrm{VHO}$ lighting provided a photosynthetic photon flux (PPF) of 340 $\mu \mathrm{mol} \cdot \mathrm{m}^{-2} \cdot \mathrm{s}^{-1}$ at canopy level for $14 \mathrm{~h}$ each day; on day 30 , daylength was reduced to $10 \mathrm{~h}$. Following the first harvest on day 10, plants were pinched to six nodes.

Treatments. The plants received either a constant application rate of $200 \mathrm{mg} \mathrm{N} /$ liter or a variable application rate. The variable treatment supplied $\mathrm{N}$ in amounts that closely matched the $\mathrm{N}$ accumulation curve of poinsettia established in previous experiments (Rose, 1993). At potting, this treatment was fertilized with $75 \mathrm{mg} \mathrm{N} / \mathrm{liter}$. The $\mathrm{N}$ concentration was increased by $25 \mathrm{mg} \mathrm{N} /$ liter about every 14 days until a maximum rate of $150 \mathrm{mg}$ N/liter was reached on day 42. On days 65 and 77, the $\mathrm{N}$ application rate was decreased to $125 \mathrm{mg} \mathrm{N} /$ liter and $100 \mathrm{mg} \mathrm{N} /$ liter, respectively. In both treatments, $\mathrm{NO}^{3}-\mathrm{N}(80 \%), \mathrm{NH}_{4}-\mathrm{N}(20 \%), 40 \mathrm{P}$, $100 \mathrm{~K}, 155 \mathrm{Ca}, 20 \mathrm{Mg}, 57 \mathrm{~S}$, and $0.5 \mathrm{Mo}$ were supplied (in $\mathrm{mg} \cdot$ liter ${ }^{-1}$ ) by $\mathrm{NH}_{4} \mathrm{~N} \mathrm{O}_{3}$, $\mathrm{Ca}\left(\mathrm{NO}_{3}\right)_{2} \cdot 4 \mathrm{H}_{2} \mathrm{O}, \mathrm{H}_{3} \mathrm{PO}_{4}, \mathrm{~K}_{2} \mathrm{SO}_{4}, \mathrm{CaCl}_{2} \cdot 2 \mathrm{H}_{2} \mathrm{O}$, $\mathrm{MgSO}_{4} \cdot 7 \mathrm{H}_{2} \mathrm{O}$, and $\left(\mathrm{NH}_{4}\right)_{6} \mathrm{M}_{7} \mathrm{O}_{24} \cdot 4 \mathrm{H}_{2} \mathrm{O}$. Drip tubes supplying individual saucers subirrigated each plant as needed; saucers retained all leachate. The total $\mathrm{N}$ applied was calculated from the volume and concentration of applied fertilizer solutions.

Harvest procedures. At 10-day intervals, one pot per treatment was taken from each of eight blocks in a randomized complete-block design. At each harvest, shoots were separated into leaves, stems (petioles included), and bracts (if present). Cyathia were included in the stem fraction; cyathia contained $\approx 6 \%$ of total shoot $\mathrm{N}$ at maturity (Rose, 1993). Separate surface area measurements were made of new leaves on the branches (when present) and basal leaves on the primary stem. Sample $\mathrm{N}$ concentrations were determinedly the Kjeldahl procedure (Bremner, 1965). Nitrogen concentrations were also determined for rooted cuttings at potting and shoot tips that were removed at pinching. No pretreatment was used with the Kjeldahl procedure because preliminary tests revealed a low nitrate- $\mathrm{N}$ concentration in poinsettia shoots $(0.1 \%$ to $0.2 \%)$.

At each harvest, the $\mathrm{pH}$ and nitrate-N concentration of growing media samples from four pots per treatment were determined using the saturated medium extract procedure (Warncke, 1988). The $\mathrm{pH}$ was measured in the slurry. The uppermost 2 to $3 \mathrm{~cm}$ of medium (upper layer) was removed for separate analysis, and the-remaining medium (lower layer) was sampled after mixing.

Photosynthesis and soluble protein. The LI-COR 6200 Portable Photosynthesis System (LI-COR, Lincoln, Neb.) was used to measure net $\mathrm{CO}_{2}$ - exchange rates (CER) of leaves and bracts on days 60, 70, and 80 . Measurements were made at uniform PPF $\left(900 \mu \mathrm{mol} \cdot \mathrm{m}^{-2} \cdot \mathrm{s}^{-1}\right)$ under a metal halide light. All leaves or bracts on one branch per plant were measured $(n=4)$. Soluble protein of the leaf and bract tissue was measured using the Bio-Rad Protein Assay Kit (Bio-Rad, Chemical Division, Richmond, Calif.).

Statistical analysis. SAS statistical procedures were used for analysis of variance and least squares mean separation (SAS Institute, Cary, N.C.).

Definitions. Vegetative stage: 30 days of long days $(14 \mathrm{~h})$ after potting. Inductive stage: 30 days of short days $(10 \mathrm{~h})$ between floral induction and visible bud. Bract development stage: 20 days of short days between visible bud and anthesis (pollen dehiscence). Nitrogen accumulation rate (NAR): the average rate of change in whole-plant $\mathrm{N}$ content over a period of time, calculated using interval formulas; interval $=10$ days (Hunt, 1990). Leaf area duration: the response area (integral, $\mathrm{cm}^{2}$ $x$ day) under the plot of leaf area vs. time (Hunt, 1990)

\section{Results}

Nitrogen accumulation and dry weight increase. At final harvest (day 80), plants in the two treatments were indistinguishable and of commercial quality; shoot $\mathrm{N}$ contents (547 $\mathrm{mg} / \mathrm{plant}$ in variable-rate treatment, $610 \mathrm{mg} /$ plant in constant-rate treatment), shoot dry weights $(16.2 \mathrm{~g} /$ plant in variable-rate treatment, $16.9 \mathrm{~g} / \mathrm{plant}$ in constant-rate treatment), and shoot $\mathrm{N}$ concentrations (Fig. 1) were not significantly different between treatments.

The patterns of shoot $\mathrm{N}$ accumulation over time also were similar between treatments and therefore are discussed jointly. NAR (Fig. 2, black bar) was lowest in the first interval after 


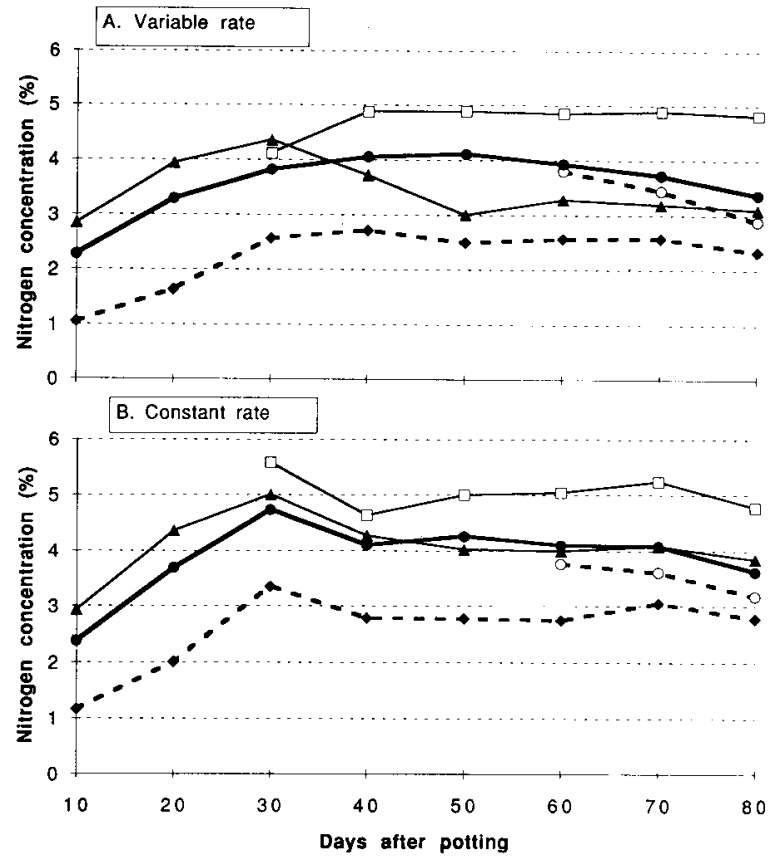

Fig. 1. Nitrogen concentration of $(\boldsymbol{A})$ basal leaves, $(\square)$ new leaves, $(\bullet)$ stems, $(\bigcirc)$ bracts, and $(\boldsymbol{O})$ whole shoots at each harvest in the $(\mathbf{A})$ variable- and $(\mathbf{B})$ constant-rate treatments $(n=8)$. potting, as rooting occurred. After day 10, NAR increased rapidly. Both shoot NAR (Fig. 2) and dry weight increase (not shown) were greatest during the inductive stage, reaching a maximum during the 10-day interval ending on day 60 . NAR decreased after day 60 throughout bract development.

Recovery efficiency. In Fig. 2, the shoot N recovery efficiency (percent, given in boxes) for each 10-day interval represents the fraction of total $\mathrm{N}$ applied (black bar plus white bar) that was recovered in the shoot (black bar). This is a crude estimate because potential carryover of $\mathrm{N}$ in the medium between intervals is ignored. Nitrogen recovery efficiency was extremely low after potting and increased as NAR increased. Nitrogen recovery was highest in the inductive stage and decreased through bract development. Nitrogen recovery for each interval was superior for the variable rate compared to the constant rate (Fig. 2), which would be expected because their total $\mathrm{N}$ contents were not significantly different. Average recovery efficiency for the duration of the experiment was $\approx 50 \%$ higher for the variable rate than for the constant rate (Table 1). Furthermore, $41 \%$ less $\mathrm{N}$ was applied with the variable than the constant rate. The $0 \%$ recovery observed in the constant rate between days 70 and 80 (Fig. 2) probably resulted from variation in plants within a treatment, between destructive harvests. If the experiment were repeated, some additional $\mathrm{N}$ accumulation over this interval would be expected to occur in the constant-rate treatment.

Surface area. Surface area duration expresses the magnitude of leaf area and its continuity over time. New leaf and bract duration were not significantly different between treatments; together these represented the greatest proportion of surface area (Fig. 3). Basal leaf area duration was significantly lower in
Table 1. Nitrogen balance sheet at final harvest, variable and constant-rate treatments (treatment averages): the total $\mathrm{N}$ applied per poinsettia plant and percent recovery in the shoot.

\begin{tabular}{lccc}
\hline \hline $\mathrm{N}$ & \multicolumn{2}{c}{$\mathrm{mg} \mathrm{N} /$ plant } & \\
\cline { 2 - 3 } $\begin{array}{l}\text { application } \\
\text { rate }\end{array}$ & $\begin{array}{c}\text { Total } \\
\mathrm{N} \text { applied }\end{array}$ & $\begin{array}{c}\text { Shoot N } \\
\text { content }\end{array}$ & $\begin{array}{r}\text { \% Shoot } \\
\text { recovery }\end{array}$ \\
\hline Variable & 950 & 547 & 58 \\
Constant & 1607 & 610 & 38 \\
\hline
\end{tabular}

relationships were observed in the constantrate treatment and, thus, are not shown. During the interval ending on day 20, basal leaves were allocated the greatest fraction of $\mathrm{N}$ and dry weight; new shoot growth had just begun. After day 20, the plant's investment in the basal leaves decreased; based on visual observation, the negative rates of change in basal leaves after day 30 probably indicated both $\mathrm{N}$ remobilization and leaf abscission. After day 20 , allocation of $\mathrm{N}$ and dry weight to the new leaves increased rapidly, reaching a maximum in the inductive stage between days 40 and 50 . After day 60, allocation of $\mathrm{N}$ to the new leaves was minimal; this also was reflected in the leaf area (Fig. 3). Allocation to stems reached a maximum between days 50 and 60; phenologically, floral buds had appeared and the first signs of color were apparent. In the next two intervals, the bracts were allocated the greatest proportion of $\mathrm{N}$ and dry weight.

Despite shifts in $\mathrm{N}$ and dry weight allocation among the various shoot components, the plant maintained a nearly constant ratio between stems and leaf-like organs, and these ratios were nearly identical between the treatments (Fig. 5, variable treatment shown only). The decreasing requirement for $\mathrm{N}$ that was observed throughout bract development was (A) and dry weight (B) of each shoot component for the variable-rate treatment; similar

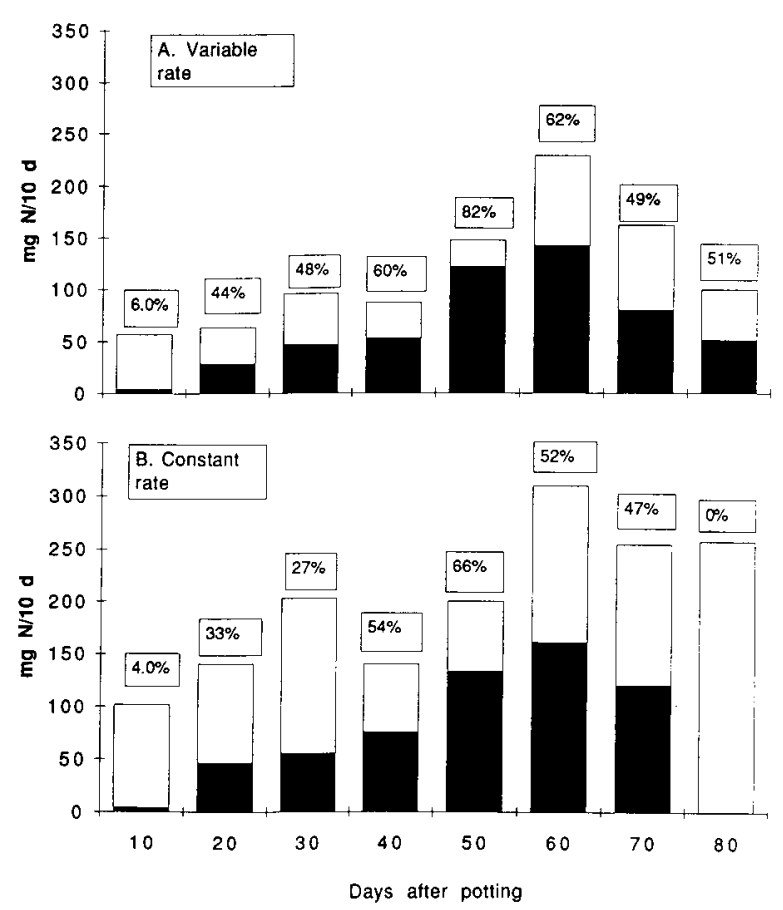

Fig, 2. Average $\mathrm{N}$ accumulation rate (black bar) and total $\mathrm{N}$ applied (black plus white bar) for 10-day intervals ending on indicated day, $(\mathbf{A})$ variable- and $(\mathbf{B})$ constant-rate treatments. The percent $\mathrm{N}$ recovered in the shoot is listed above each bar $(n=8)$. 


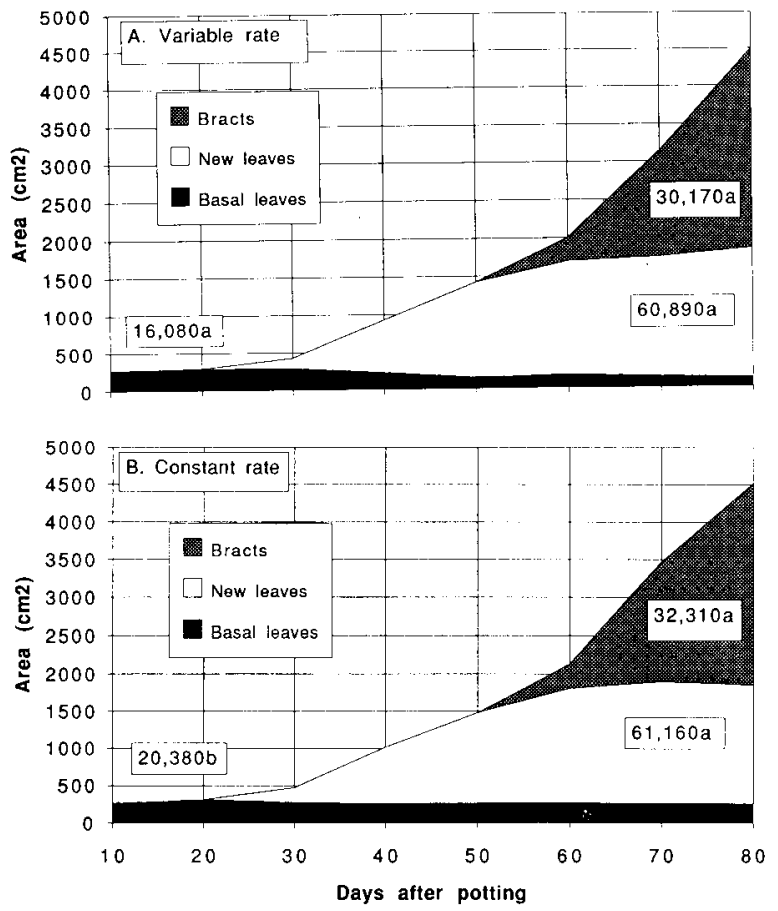

Fig. 3. Surface area and area duration of basal leaves, new leaves, and bracts. The area duration $\left(\mathrm{cm}^{3} \times \mathrm{d}\right)$ is given in the boxes. Statistical differences in area duration between the treatments for corresponding organs is noted by $a, b(n=8)$

due to the plant's allocation of resources to a tissue having a lower $\mathrm{N}$ concentration than leaves. During the bract development period, the average new leaf $\mathrm{N}$ concentration for both treatments was $\approx 5 \%$, whereas $\mathrm{N}$ concentration in the bracts ranged between $3 \%$ to $4 \%$ (Fig. 1).

Photosynthesis and soluble protein. Net photosynthetic CER was similar for the treatments. Between days 60 and 80, as the leaves became shaded by elongating bracts, CER in green leaves decreased by $50 \%$ in both treatments (data not shown). At final harvest (day 80 ), the average CER of green leaves, leaves in transition ( $<50 \%$ green tissue), and bracts were 4.6, 2.4, and $0.3 \mu \mathrm{mol} \cdot \mathrm{m}^{-2} \cdot \mathrm{s}^{-1}$, respectively (treatments averaged). These data provide evidence that the organs in transition from leaves to bracts lose their photosynthetic capacity gradually. However, deep purple-green leaves that appeared to have both chlorophyll and anthocyanins had CER levels indistinguishable from or even higher than green leaves.

At day 80, soluble protein levels in the bracts were $<15 \%$ of those found in green leaves (data not shown). There were no significant differences between treatments.

Medium analysis. At most harvests, significantly higher nitrate-N concentrations were found in the container medium (upper and lower layers) of the constant- than in the variable-rate treatment (Fig. 6). The nitrate-N concentrations in the lower medium layers of both treatments inversely reflected the $\mathrm{N}$ demand of the crop. Nitrate- $\mathrm{N}$ concentration in the medium increased through the vegetative stage while NARs were low, and reached a plateau during the induction stage when $\mathrm{N}$ demand was greatest. The plant requirement for $\mathrm{N}$ appeared to have been met by both treatments because shoot $\mathrm{N}$ concentrations and contents were similar for treatments. The steep increase in nitrate- $\mathrm{N}$ concentration that occurred after day 50 in the constant-rate treatment (Fig. 6) suggested that $\mathrm{N}$ applied to this treatment exceeded the crop requirement. was removed by pinching $(\mathrm{n}=8)$.
The excessive concentration of nitrate- $\mathrm{N}$ observed in the upper layer of medium in both treatments (Fig. 6) is typical of subirrigation and represented a substantial fraction of the applied $\mathrm{N}$ that was probably unavailable to the plant. The nitrate- $\mathrm{N}$ in the upper layer was estimated to be $14 \%$ and $21 \%$ of the total $\mathrm{N}$ applied to the variable-and constant-rate treatments, respectively.

The $\mathrm{pH}$ of the lower layer of medium at final harvest (data not shown) was 6.4 and 5.9 for the variable- and constant-rate treatment, respectively. We have observed in this and related experiments that decreasing the $\mathrm{N}$ application rate contributes to a higher medium $\mathrm{pH}$, Growers intending to grow crops at minimal $\mathrm{N}$ application rates may need to adjust their growing medium amendments.

\section{Discussion and Conclusions}

The simple strategy of $\mathrm{N}$ fertilization used in the variable-rate treatment, increasing or decreasing the $\mathrm{N}$ application rate to reflect whole-shoot NAR, succeeded in reducing $\mathrm{N}$ use and increasing $\mathrm{N}$ recovery efficiency. While significantly more $\mathrm{N}$ accumulated in the growing medium of the constant-rate treatment, this treatment did not produce plants with higher shoot $\mathrm{N}$ contents, $\mathrm{N}$ concentrations, or dry weights at final harvest.

Nitrogen accumulation in poinsettia followed a predictable pattern of low but increasing NARs in the vegetative growth stage, maximum NARs in the inductive stage, and decreasing NARs through bract development. The maximum NAR, and hence the greatest

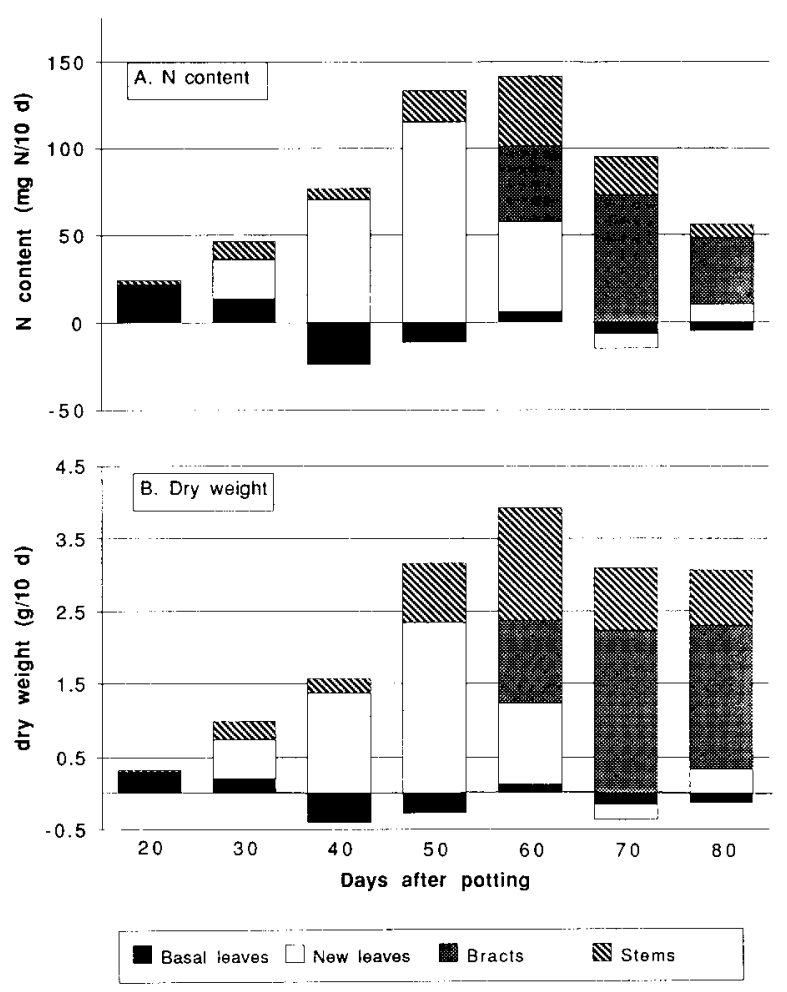

Fig. 4. Average change in (A) $\mathrm{N}$ content and (B) dry weight of the shoot components for 10-day intervals ending on indicated day, variable-rate treatment. Not shown for the first 10-day interval because growth 


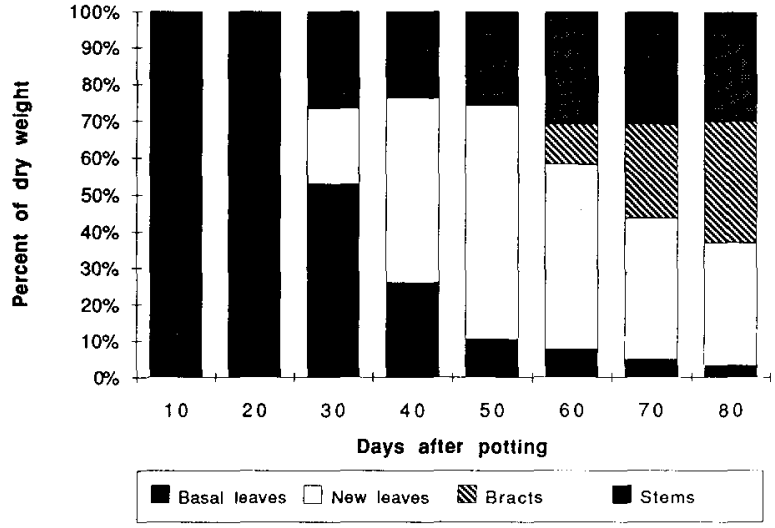

Fig. 5. Percent of total shoot dry weight allocated to basal leaves, new leaves, stems, and bracts for 10-day intervals ending indicated day, variable-rate treatment $(n=8)$.

requirement for $\mathrm{N}$, occurred when plants were allocating the greatest proportion of $\mathrm{N}$ and dry weight to leaf tissue. The $\mathrm{N}$ requirement of poinsettia decreased when the plant shifted its resources to the production of bract tissue, which had a lower concentration of $\mathrm{N}$ than leaves. A lower physiological requirement for $\mathrm{N}$ in bract tissue was implied by the much lower rates of $\mathrm{CO}_{2}$ exchange and soluble protein in bracts compared to leaves. The low soluble protein levels suggested that bracts had lower levels of the $\mathrm{CO}_{2}$-fixing enzyme ribulose bisphosphate carboxylase (rubisco) than leaves. Rubisco represents a large fraction of total plant protein and is the single largest sink for N in the plant (Sharkey, 1991).

The shift in dry-weight accumulation and the reduction in $\mathrm{N}$ requirement that accompanied bract development was predetermined by floral induction. The changes induced by floral development explain why the $\mathrm{N}$ contents and dry weights were similar for the treatments and why little or no luxury $\mathrm{N}$ consumption was observed in the treatment receiving the higher $\mathrm{N}$ concentration. Tsutsui and Aoki (1981) also noted satisfactory growth and little difference in dry weight and shoot $\mathrm{N}$ concentration in poinsettias supplied with 126 or 210 $\mathrm{mg} N /$ liter. Poinsettias grown vegetatively would probably respond more to additional $\mathrm{N}$.

Staby and Kofranek (1979) indicated that fertilization may be discontinued as early as 4 weeks before poinsettia maturity, and this is commonly practiced among growers. Although we demonstrated that poinsettias continue to accumulate $\mathrm{N}$ in the bracts and stems in the later stages of development, poinsettia nutrition probably has not been impaired by discontinuing fertilizer because higher fertilization rates than necessary are used. The application rate of $300 \mathrm{mg}$ N/liter used by Staby and Kofranek probably produced substantial fertilizer reserves in the medium before bract development. If our fertilization strategy is adopted, $\mathrm{N}$ application through maturity may be required.

Growth analysis was used to describe the growth of poinsettia and its $\mathrm{N}$ requirement quantitatively. The most useful growth analysis quantities for relating $\mathrm{N}$ use to growth stage were 1) the average rates of change in shoot $\mathrm{N}$ content (referred to as the $\mathrm{N}$ accumulation rate), which revealed when the plant used relatively more or less $\mathrm{N}$, and 2) the average rates of change in $\mathrm{N}$ content and dry weight of the shoot components, which revealed when and where the plant used $\mathrm{N}$. The simple growth analysis procedures used in these experiments are useful not only for describing how, when, and where a plant uses an element, but also for identifying windows of opportunity for the amelioration of nutrient deficiencies, or for tailoring new formulations of slow-release fertilizers to the nutritional needs of specific crops. However, the change in nutrient recovery efficiency that occurs throughout plant development increases the complexity of predicting adequate fertilizer application, even though one can approximate the plant's total $\mathrm{N}$ requirement from the rate of $\mathrm{N}$ accumulation.

\section{Literature Cited}

Argo, W.R. and J.A. Biernbaum. 1991. The effect of fertilizer, nutrient charge, and irrigation method on early vegetative and root growth of poinsettia 'V-14 Glory'. HortScience 26(6):763. (Abstr.)

Bremner, J.M. 1965. Total nitrogen, p. 1149-1178 In: C.A. Black (ed.). Methods of soil analysis. Part 2. Amer. Soc. Agron., Madison, Wis.

Hershey, D.R. and J.L. Paul. 1982. Leaching-losses of $\mathrm{N}$ from pot chrysanthemums with controlledrelease or liquid fertilization, Scientia Hort. 17:145-152.

Hunt, R. 1990. Basic growth analysis: Plant analysis for beginners. Unwin Hyman, London.

King, J. and D. Stimart. 1990. Quantities and forms of $\mathrm{N}$ uptake throughout development in chrysanthemum. HortScience 25(9):1170. (Abstr.)

Newman, J.P., J.H. Lieth, and B. Faber. 1992. Effect of an irrigation system controlled by soil moisture tension in reducing water usage and run-off in poinsettia production. HortScience 27(6):640-641 (Abstr.)

Rose, M.A. 1993. Nitrogen use, recovery efficiency, and growth analysis of poinsettia. PhD Diss., The Pennsylvania State Univ., University Park.

Sharkey, T.D. 1991. Photometric method for routine determination of $\mathrm{K}_{\mathrm{CAT}}$ and carbamylation of rubisco, Photosynthesis Res. 28:41-48.

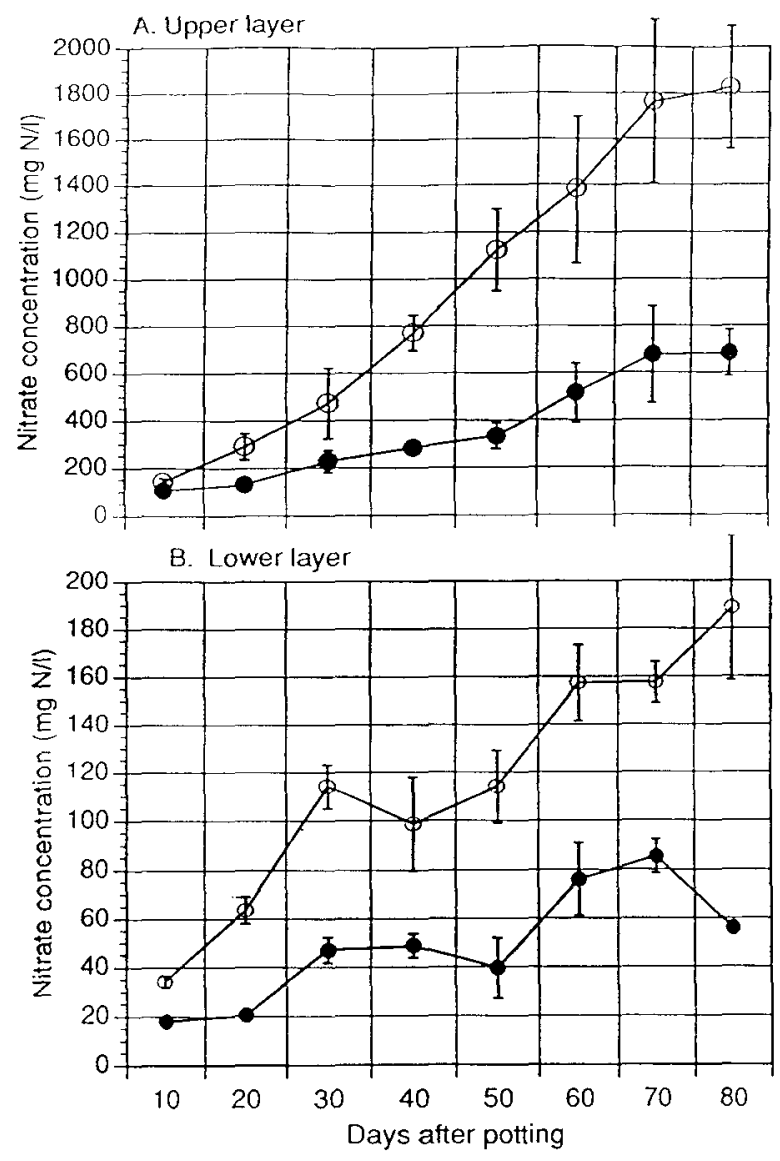

Fig. 6. Nitrate-N concentrations of the (A) upper and (B) lower layers of container medium in the variable- and $(O)$ constant-rate treatments. Error bars indicate $S E(n=4)$. 
Staby, G.L. and A.M. Kofranek. 1979. Production conditions as they affect harvest and postharves characteristics of poinsettias. J. Amer. Soc. Hort. Sci. 104(1):88-92.

Stewart, J.A., L.J. Lund, and R.L. Branson. 1981. Nitrogen balances for container-grown privet. J. Amer. Soc. Hort. Sci. 106(5):565-569.
Tsutsui, K. and M. Aoki. 1981. Response of poinsettias to major nutrient supply in relation to nutrient uptake and growth. Bul. Veg. Ornamental Crops Res. Sta. Ano Jpn. Ser. A. 8:171-207.

Warncke, D. 1988. Recommended test procedure for greenhouse growth media, p. 34-37. In: W.C. Dahnke (ed.). Recommended chemical soil test procedures for the north central region. North Central Regional Publ. 221 (revised).

Yelanich, M.V. and J.A. Biernbaum. 1990. Effect of fertilizer concentration and method of application on media nutrient content, $\mathrm{N}$ runoff and growth of Euphorbia pulcherrima V-14 Glory. Acta Hort. 272:185-189. 